\title{
How Preference Markets Assist New Product Idea Screening
}

\author{
Lauto, Giancarlo; Valentin, Finn
}

Document Version

Accepted author manuscript

Published in:

Industrial Management \& Data Systems

DOI:

10.1108/IMDS-07-2015-0320

Publication date:

2016

License

Unspecified

Citation for published version (APA):

Lauto, G., \& Valentin, F. (2016). How Preference Markets Assist New Product Idea Screening. Industrial Management \& Data Systems, 116(3), 603-619. https://doi.org/10.1108/IMDS-07-2015-0320

Link to publication in CBS Research Portal

\section{General rights}

Copyright and moral rights for the publications made accessible in the public portal are retained by the authors and/or other copyright owners and it is a condition of accessing publications that users recognise and abide by the legal requirements associated with these rights.

Take down policy

If you believe that this document breaches copyright please contact us (research.lib@cbs.dk) providing details, and we will remove access to the work immediately and investigate your claim. 


\title{
How Preference Markets Assist New Product Idea Screening
}

\author{
Giancarlo Lauto and Finn Valentin
}

Journal article (Post print version)

Cite: How Preference Markets Assist New Product Idea Screening/Lauto, Giancarlo; Valentin, Finn. In: Industrial Management \& Data Systems, Vol. 116, Issue 3, २016, p. 603-619.

DOI: 10.1108/IMDS-07-2015-0320

Uploaded to Research@CBS: May २०16 
Introduction

Information technology-enabled games are being seen as management tools to assist problemsolving in a broad range of areas including marketing, education, and healthcare (Harman et al. 2014). Online innovation contests are a form of gamification of the new product development (NPD) process and are increasingly being recognized as enablers of open innovation strategies (Bayus 2013), and as integration tools in large and geographically dispersed research and development (R\&D) teams (van Dijk \& van den Ende 2002; Simula \& Ahola 2014). An important advantage of innovation contests is that they allow companies to manage the critical tension in NPD between the breadth of idea generation and the quality of screening and selection.

Despite their increasing adoption, there is little systematic evidence on internal innovation contests. Some notable exceptions are the studies by Spears et al. (2009), Chen et al. (2009), LaComb et al. (2007), Santos and Spann (2011) and Soukhoroukova et al. (2012) which emphasize their effectiveness for eliciting creativity, mobilizing existing knowledge, and enhancing communication. They are known also to improve the screening and selection of large pools of new product ideas, a task traditionally carried out by small committees of R\&D managers. An expert crowd can economize on managers' valuable time and attention by highlighting the most promising ideas.

Understanding the critical task of idea evaluation is an open research problem in the field of innovation contests (Adamczyk et al. 2012). A crucial issue, so far neglected in the literature, concerns the extent to which a crowd uses different criteria to evaluate a new product idea, and relies on different types of information compared to a management committee. This is a particularly relevant issue and invites a better understanding of the information-seeking and decision-making processes of groups engaged in complex evaluation tasks, and a better appreciation of the effect of structural features such as composition and background (i.e. a small committee with managerial experience vs. a large crowd of researchers and technical experts). This can have direct implications 
for the design and planning of innovation contests: understanding whether committees and crowds rely on diverging or overlapping information in their evaluations, justifies use of crowds for idea screening to contribute new insights to those offered by committees.

The questions that motivate our analysis are whether the features of ideas that crowds and committees associate with higher quality are similar or different, and what strategies crowds and committees adopt to evaluate new product ideas under conditions of bounded rationality.

We address these questions by analyzing an innovation contest implemented by the Danish multinational company Novozymes. The company launched an internal idea generation project aimed at identifying an invention with high market potential in the field of industrial enzymes. The contest was open to a selected group of employees from the company's eight research centers located in six countries, and involved a committee composed of managers from the R\&D department involved in various stages of the NPD process. A virtual preference market was designed to accompany idea generation and selection.

This empirical setting allows direct comparison of the preferences of a crowd of experts and a management committee. Since both groups rely on similar information about the projects and the inventors, we are able to assess what drives the divergences in their evaluations.

This paper is one of the first empirical studies to compare a committee's vis-à-vis crowd's rationality in a complex problem solving setting such as idea generation - a phenomenon that has been theorized only recently (Afuah \& Tucci 2012; Poetz \& Schreier 2012). Specifically, we find that the crowd and the management committee associate different aspects of proposals to quality: the former tends to focus on the characteristics of the ideas, and the latter on the characteristics of the inventors. This result seems consistent with the notion that bounded rationality drives decisionmakers to rely on heuristics and knowledge that are closest to their expertise. Also, we find that 
crowds, like other decision-makers, are subject to a threshold in their ability to process information. These findings suggest that companies should adopt preference market-based innovation contests to complement rather than to substitute for traditional managerial evaluation in the NPD process.

The rest of the paper is structured as follows: in section 2 we develop the theoretical framework and hypotheses; section 3 presents the research setting and section 4 discusses the empirical results. The paper concludes with a discussion of the findings, and some managerial implications and perspectives for future research.

\section{Theoretical framework and hypotheses}

\section{Innovation contests as a mechanism for idea generation}

In line with Xu et al. (2014), we suggest that NPD in research-based industries builds essentially on knowledge management capabilities. Therefore, innovative companies should develop methods for the systematic acquisition, elaboration, recombination, application and retention of scientific, technological, and market knowledge. These systems should be designed with the purpose of disseminating and integrating this formal and informal knowledge among all the units involved in the NPD process, and their use should be endorsed by authoritative figures in the organization (Pitt \& MacVaugh 2008). Empirical studies show that the implementation of knowledge management systems is associated with reduced time to market and enhanced new product performance (Vaccaro et al. 2010).

A key issue in the design of knowledge management system is the awareness of users of the available information, and therefore, its exploitation (Khedhaouria \& Jamal, 2015). NPD is exposed to the risk of redundancy and underutilization of available information due to the number of units involved and the amount of information required for successful completion of the process. Research in this area focuses on the development of systems that facilitate knowledge acquisition and sharing 
in collaborative teams (e.g. Zhen et al. 2013) and assist groups in preference decisions such as evaluation, prioritization, and selection, in conditions of multiple and conflicting criteria (e.g. Chiu et al. 2006).

Innovation contests have emerged as a tool that encompasses the activities of idea generation, knowledge sharing, and prioritization and selection. Examination and ranking of ideas is at the core of NPD models (Magnusson et al. 2014), and since it entails specific managerial challenges, marks the conclusion of the idea generation stage. In the early idea generation stage, $R \& D$ organizations seek to increase the volume and variety of knowledge sources (Yang \& Rui 2009) in order to benefit from opportunities for recombination and integration (Fleming \& Sorenson 2001), while selection of ideas calls for a concentration of the evaluator's cognitive resources on the most promising proposals.

However, the limited cognitive resources and attention of $R \& D$ management preclude thorough examination of large sets of ideas: managerial committees tend to be selective and to address proposals that are closest to their experience (Piezunka \& Dahlander 2014; Haas et al. 2015). In addition, small group dynamics might bias the quality of the evaluation. Gamification of the NPD process, e.g. via innovation contests, allows an increased number of potential proposals while protecting key decision-makers from information overload (Soukhoroukova et al. 2012), and the firm from missing potential technological opportunities. Figure 1 summarizes the contributions of innovation contests to NPD.

Figure 1. Major advantages of innovation contests in the NPD process.

\section{$===$ PLEASE, INSERT FIGURE 1 ABOUT HERE===}

Innovation contests are designed to allow participants to propose solutions to challenges defined by the organizing firms, in exchange for a reward for the best ideas/solutions. A committee of internal 
experts, sometimes assisted by participants, filters the proposals to identify those that could be valuable to the company. The selected ideas then undergo a maturation process to improve their technical or commercial feasibility (Piller \& Walcher 2006).

Research has identified the conditions where involvement of a broad community is the preferred means to address an innovation objective, especially if the firm is exploring solutions outside its technological competences. The firm should be able effectively to convey the problem, to involve a heterogeneous pool of participants, to evaluate large numbers of ideas, and to manage the information technology infrastructure necessary to support the contest (Afuah and Tucci, 2012). In the screening and evaluation of ideas, an organizer evaluates the solutions proposed by participants, from multiple perspectives including feasibility, fit with the firm's competencies, and expected return on investment. This task is demanding of managerial attention because innovation contests provoke numerous ideas, very few of which are valuable from a business perspective (Mortara et al. 2013). This implies that companies should consider the potential trade-offs between variety of ideas, the quality of ideas, and managerial attention.

\section{Improving the efficiency of idea screening with preference markets}

The task of idea evaluation typically is carried out by company experts assisted by specific decision support systems (Chan \& Ip 2010); however, it may be devolved to a crowd and managed as a game, e.g. by means of a preference market, a tool that permits the integration of idea generation and idea evaluation (Slamka et al. 2012).

Participants in a preference market submit their own ideas to a virtual platform, and assess their peers' ideas using a trading mechanism. Each idea is represented by a security, and participants trade securities using play money. Assuming that trading decisions reflect participants' evaluations of the quality of the ideas, it is possible to rank them using information generated in the market - 
e.g. volume-weighted average trading price, or the last fixed price. Organizers motivate traders to reveal their preferences by offering a reward based on the value of their share portfolio and play money. The functioning of preference markets rests on the notion of "crowdsourcing" where the aggregation of a large number of individual opinions, although biased, is more effective than the judgments of a small group of experts (Surowiecki 2004). Thus, aggregation of information provided by a pool of independent participants is expected to reveal the quality of the ideas. However, it is not possible to compare the outcomes of a preference market with the "real" value of the ideas: only a few ideas are subsequently developed and become products; and also, the revenues generated by those products are revealed only years after the their launch. For these reasons, panels of experts determine the final ranking of ideas presented in a preference market (Slamka et al. 2012).

\section{Hypotheses about the decision-making of committees and crowds}

From a behavioral perspective, the decisions made by individuals and teams in the NPD screening and selection stages, are subject to bounded rationality due to the limited available information, and constraints related to the agents' cognitive resources, time, and attention (Cyert \& March 1963; March \& Simon 1958). The impossibility of a complete understanding of the environmental dynamics, drives the actors to conduct their screening and selection based on specialisms in specific domains (Krishnan \& Ulrich 2001), problems that are proximate to their existing scientific and technological expertise (Tripsas \& Gavetti 2000), and heuristics enabling prioritization among projects (Ocasio 1997; Bentzen et al. 2011).

In the case of NPD, managers tend to focus on different attributes depending on their seniority (senior vs. middle management), and the type of experience accumulated in their position through learning by doing (Behrens et al. 2014). This theoretical approach throws light on how crowds and committees differ in their evaluation of novel product concepts and technologies. 
Scientists are influenced by the nature of their jobs which require rational decision-making and critical thinking, and they tend to rely more on logic and objective data in their work decisions, compared to other professions (Lounsbury et al. 2012). In an innovation contest, the judgment of an expert crowd is based mostly on information about the idea disclosed by the inventor at submission, and on information generated during the competition, e.g. by trading dynamics in the preference market. We would expect crowds to focus on proposals accompanied by rich and complete information since this allows thorough examination of their technological and competitive strengths and weaknesses. Committees also value information on the ideas but are able to supplement it with additional information on the inventors.

We argue that the attitudes to decision making of a committee and of a crowd of R\&D professionals differ, because R\&D managers ground their NPD decisions on both rational/analytic reasoning and on intuition (Eling et al. 2014) and interpretation of signals (Bentzen et al. 2011). Reputation is a mechanism that reduces complexity in decision making (Ferris et al. 2014; Ching et al. 1992), so evaluators will direct their limited attention and cognitive resources to ideas submitted by employees who signal better innovation capabilities. Specifically, inventors' experience in patenting, scientific publishing, and idea generation is an objective indicator of innovation capabilities (Subramanian et al. 2013). Tenure in the organization can play a similar role since it is associated with deeper knowledge of the priorities and routines of the R\&D department; this knowledge combined with creativity, greatly enhances an employee's ability to generate discontinuous inventions. These criteria are more relevant to a committee in particular because they indicate an inventor's ability to generate proposals that will provide competitive advantage, a new product idea attribute that is valued highly especially by middle R\&D management (Behrens et al. 2014). We hypothesize that: 
Hypothesis-1: A crowd and a committee assess new product proposals with reference to different attributes; specifically, crowds privilege idea-related features while management committees prioritize inventor-related features.

We have suggested that the process of idea screening and selection is subject to bounded rationality, cognitive specialization, and limited attention of decision-makers. Therefore, we expect that proposals containing very detailed idea descriptions quickly saturate evaluators' attention; they may include unnecessary issues, and may be more difficult to interpret. Information overload occurs when inventors convey information through multiple channels which increases redundancies (Liu 1998; Citroen 2011; Soukhoroukova et al. 2012). This is a relevant problem in our case if inventors supplement textual descriptions with links and attachments. Given the bounded rationality of evaluators, these ideas will attract a lower ranking. We expect this constraint to affect crowds more than management committees, because crowds make their decisions based mostly on information about the idea. Therefore, we hypothesize that:

Hypothesis-2: In crowd's evaluation, the quality of new product ideas is associated with the availability of a moderate amount of information.

Figure 2 summarizes the key relationships examined in our study.

Figure 2. Graphical representation of the conceptual model.

$===$ PLEASE, INSERT FIGURE 2 ABOUT HERE===

(C) Emerald Group Publishing Limited 


\section{Empirical setting}

\section{Grow Bets 2011}

The empirical setting of our study is the innovation contest "Grow Bets 2011" launched by the Danish biotech company Novozymes with the purpose of identifying inventions with the potential to outperform existing technologies and open up valuable market opportunities. Novozymes is a world leader in the production of industrial enzymes and microorganisms, and sells over 700 products in 130 different countries and 40 different industries. When the campaign was launched in October 2011, the company had 5,400 employees, 1,024 of whom worked in its R\&D organization. Its laboratories are located in Denmark, the USA (3 sites), Brazil, China, India and Japan.

Novozymes' Innovation Office, the unit of the R\&D department that facilitates NPD initiatives, designed an internal innovation contest with the objective of boosting idea generation while decreasing the complexity of evaluation.

\section{Structure of the contest}

The contest was structured in three stages:

- Idea generation and evaluation by means of a virtual platform including a preference market, open to a crowd selected from the $R \& D$ department. The ten ideas with the highest value at the close of the preference market were presented to the senior R\&D management for a further screening;

- Selection of 15 valuable ideas among those ranked below $10^{\text {th }}$ position in the preference market. This task was assigned to the "Screen Team", a committee composed of seven R\&D managers tasked with re-considering ideas that the crowd might have overlooked; 
- Maturation of 5 ideas selected by senior R\&D management from among the 25 identified by the crowd and the Screen Team. Top management had the final decision on which ideas should progress to the later stages of the NPD process.

The design of the contest offers the methodological opportunity to compare the attributes of the proposals that the participants in the market and the members of the Screen Team associated with idea value. Our units of analysis are the ideas ranked lower than $10^{\text {th }}$ position in the market because these were the ideas evaluated by both the crowd and the committee.

\section{The preference market}

The participants in the contest were selected by a group of senior members of the R\&D and business development departments from among employees with high innovation potential. Participation was restricted to an "elite" group in order to increase ideation efficiency; however, this choice potentially reduces knowledge base heterogeneity. To avoid this limitation, variety in discipline, rank, and geography was assured.

The virtual platform for idea generation and trading was open for 12 working days. Participants could submit as many ideas as they wished. Only six inventors made use of the option to submit ideas anonymously. Inventors were mandated to provide a textual description of the idea, and had the option to attach an unlimited number of documents and to include links to Internet websites. Participants could search the ideas which were categorized into three broad areas referring to the application of the invention.

Each idea represented a share in the market. When the market opened, participants were given an amount of virtual dollars which they could invest in the ideas considered to have the best potential as a new product; shares could also be sold, e.g. if newly submitted ideas were more attractive. 
Purchase of shares in one's own ideas, and short-selling, were not allowed. Transactions were concluded not by matching buy and sell orders but by means of an automated market maker: all orders were executed instantly, and provoked variations in the price of shares based on the amount traded, according to an algorithm developed by Hanson (2007). Participants gathered information on ideas by looking at their prices, their descriptions, and the comments posed by participants to offer feedback to inventors and information to investors.

Participants had easy access via the company's internal directory, to information on the ranks and work positions of inventors, and could obtain information on prior patenting and publication from databases accessible to R\&D staff. Therefore, both the Screen Team and the participants had access to the same pool of information although we do not know which data they utilized. Therefore, differences in the kind of information associated with quality should be attributed not to its availability but to its use.

To incentivize participants to invest in the ideas which they believed had the highest potential, the Innovation Office rewarded the traders with the most valuable portfolios at the close of the market. Although the prizes were symbolic, they were awarded during a ceremony which gave considerable internal visibility to the winners.

\section{Participation in the innovation contest}

The Innovation Office invited 145 employees to participate and 109 took up the invitation: 74 submitted ideas and 101 traded on the preference market. Table 1 summarizes the demographic profiles of participants. At the end of the campaign, 222 ideas had been submitted, half that number during the first 5 days of the contest. About $50 \%$ of the inventors presented one idea, and about $10 \%$ presented more than seven ideas. The market value of the shares at the close of the market ranged between 0 and 30,391. Valuable ideas were scarce: 46 (20\%) closed with a market value 
equal to zero (and 14 ideas were never traded). The median market value $(1,770)$ is notably lower than the mean $(3,855)$ and the value of the $10^{\text {th }}$ idea $(17,560)$.

\section{$===$ PLEASE, INSERT TABLE 1 ABOUT HERE===}

\section{Analytical strategy}

Our analytical strategy is aimed at identifying the attributes of new product ideas that the participants in the preference market and the Screen Team associate to quality.

We excluded from the analysis ideas that were submitted anonymously and ideas where complete details on inventors are not available; one Screen Team choice is excluded for these reasons. This procedure led us to consider 201 of the 212 ideas ranking below $10^{\text {th }}$ position in the preference market. Table 2 summarizes the variables used to characterize the ideas and their measures.

\section{$===$ PLEASE, INSERT TABLE 2 ABOUT HERE $===$}

After conducting a descriptive analysis, we ran regression analyses to estimate screen team choice (STC) using a probit model, and final market value (FMV) using a Tobit model. The FMV variable is constrained between 0 and 17,559 , i.e. the FMV of the $10^{\text {th }}$ idea minus 1 . All the models present the coefficients and the marginal effects at the medians. For the two FMV models which rely on interaction effects, we perform graphical analysis and disaggregation of the interaction effect recommended by Bowen (2012). We cluster robust standard errors based on inventor or inventing team, to account for possible correlation of observations. We can exclude significant bias in our results from multicollinearity since the maximum variable inflation factor in the interacted model is 4.94, below the threshold of 10 , even though the highest correlation coefficient among the independent variables is 0.61 . The full correlation matrix is available upon request. Statistical significance at $1 \%, 5 \%$ and $10 \%$ level is indicated by ${ }^{* * *}$ and ${ }^{* * *}$ respectively. 


\section{Results}

\section{Descriptive statistics}

First, we find that the outcomes of the evaluations by the Screen Team and the crowd are broadly but not perfectly aligned: the Screen Team chose only two ideas ranked below $51^{\text {st }}$ position in the market, six ideas among those ranked between $31^{\text {st }}$ and $50^{\text {th }}$, and six among those ranked between the $11^{\text {th }}$ and $30^{\text {th }}$ positions.

Tables 3 and 4 describe the features of the inventors and the ideas, highlighting their association with FMV and STC. First, we consider the signaling effect of inventors' innovation experience. As expected, given the criteria for selection of participants, the majority of ideas were from inventors who had already patented, had authored a scientific paper, or had contributed to the IdeaWeb. Both the crowd and the Screen Team rewarded participation in the IdeaWeb, and rewarded patenting higher than scientific publishing. Seniority is positively correlated to STC and uncorrelated to FMV. In relation to the features of ideas, a longer description is weakly correlated to a higher FMV and to STC. Few ideas included links and attachments, and those that did, seemed to receive less positive evaluations.

\section{$===$ PLEASE, INSERT TABLES 3 and 4 ABOUT HERE===}

\section{Regression analysis}

Table 5 presents the results of the regression analysis. Model 1 analyzes the factors associated with STC, and model 2 considers the preference market, taking FMV as the dependent variable. Models 3 and 4 consider whether the presence of links (3) and attachments (4) in a lengthy idea description reduce its value by adding unnecessary information. 
The models reveal that the only proposal attribute associated with a positive assessment by both the crowd and the Screen Team is contribution to the IdeaWeb. Otherwise, the crowd and the Screen Team seem to gauge ideas based on different criteria, which supports Hypothesis-1.

The features that are significantly associated with STC are those related to the attributes of inventors: previous patenting experience, scientific publishing, seniority, and as already mentioned, contribution to the IdeaWeb. In contrast to other kinds of experience, scientific publishing is negatively associated with selection, suggesting that a speculative attitude may indicate a lower ability to accomplish an innovation project. We suggest the positive effect of seniority might result from senior employees better ability to interpret the company's innovation strategy, and thus to direct their creative efforts to ideas that match such priorities, and their possibly higher visibility to the Screen Team.

The attributes related to inventors (with the exception of contribution to the IdeaWeb) seem not to be considered by the crowd which instead, focuses on the features of ideas. Model 2 indicates that FMV is positively associated to the length of the idea description, negatively associated to the presence of links, and not associated to attachments.

These results do not offer conclusive insights on the relationship between the amount of information offered by the description and the market value, because they do not consider the interplay between these different sources. Models 3 and 4 are consistent in indicating that when neither links nor attachments are present, a lengthier description is positively associated to FMV; however, the negative sign of the interaction term indicates that the introduction of links or attachments in ideas with long descriptions reduces their value. This means that additional sources create an overabundance of information which seems to confuse evaluators. To better appreciate this relationship, 
we use the estimates of models 3 and 4 to calculate the impact of links and attachment on FMV at relevant percentiles of the distribution of Words (Table 6).

\section{$===$ PLEASE, INSERT TABLE 6 ABOUT HERE===}

The introduction of links and attachments is associated to a decrease in FMV for idea descriptions longer respectively than the $75^{\text {th }}$ and $90^{\text {th }}$ percentile of the distribution of Words; interestingly, attachments tend to improve the FMV of ideas whose description is in the $10^{\text {th }}$ percentile of length. In other words, inventors who offer copious information seem to be penalized compared to those who present a balanced mix of sources. We interpret this finding as indicating that the crowd is unable efficiently to process large amounts of information from different sources. However, the length of idea description, and the presence of optional sources are positively correlated, indicating that inventors do not seem to perceive the different sources of information as substitutes. Overall, these results provide support for Hypothesis-2.

\section{Conclusion}

This paper examined a preference market-based innovation contest to compare the attributes of ideas that are assessed favorably by a committee of managers and a crowd of expert scientists and R\&D professionals. This innovation contest was effective in achieving simultaneously large-scale idea generation, circulation and transformation of knowledge held by individuals and groups (Ho et al. 2014), and direction of managerial attention towards the most promising early product ideas. This suggests that innovation contests, while respecting the principle of segregation between invention and evaluation activities (Demerest 1997), close the gap between them, and help to address the critical issue of prioritization of information in the NPD process (Bradfield \& Gao 2007). Our study contributes to an emerging field of research on preference market-based innovation contests (e.g. Soukhoroukova et al. 2012). It offers new evidence to support the notion 
that in large, research-based companies these tools enhance the innovation process. Also, we highlight that effective knowledge management for NPD requires an appropriate infrastructure (Pandey \& Dutta 2013), in this case in the form of a contest combining the advantages of a crowd and a management committee.

Our main finding concerns the difference in the evaluations of crowds and committees. The empirical study shows that the crowd formulated its judgment based on information that would have been overlooked by the committee, and vice versa. The outcomes of the crowd's and the committee's judgments overlap in some respects, and differ critically in others. This result resonates with the findings in Piezunka and Dahlander (2015) concerning the decrease in organizations' attention particularly on suggestions generated by a crowd which are far from the existing knowledge base. Therefore, reliance on multiple evaluation mechanisms is important for the assessment of discontinuous innovations.

We provide evidence also that a preference market is effective for assisting problem solving but does not eliminate typical decision making issues such as information overload. Specifically, we found that crowds may overlook more articulated ideas that require lengthy textual descriptions and complementary references. While emphasizing that preference markets should be used to complement traditional evaluation tools, this result is particularly relevant since crowds have been regarded as better able than individuals and small groups to cope with information overflow in decision making. In this sense, we have identified a boundary to the "wisdom of crowds".

These findings are in line with recent studies cautioning that the adoption of knowledge management systems may lead to a rapid proliferation of the available information, beyond the ability of users to process it (e.g. Pandey \& Dutta 2013). Consistent with previous studies (Ocasio 1997; Krishnan \& Ulrich 2001) our findings suggest that in such situations of information overload, 
actors deselect overly complex, lengthy information or rely on other signals of valid solutions such as proponents' reputation (Ferris et al. 2014; Bentzen 2011)

The literature on knowledge management in NPD predominantly has focused on the study of methodologies for information retrieval and circulation in the late stages of the process (e.g. Bradfield \& Gao 2007; Xu 2014), or the design of multi-criteria group decision support systems (e.g. Chiu et al. 2006). Our findings suggest that new insights may be gained from focusing also on the organizational consequences of tools such as innovation contests that address the initial stages of idea generation and screening.

Our study offers an important indication to organizations interested in adopting innovation contests: the combination of both crowds and existing $\mathrm{R} \& \mathrm{D}$ practices is essential, as they adopt complementary perspectives to idea screening and evaluation. The results also offer advice for inventors: in our case, those who provide long idea description also tend to supplement them with additional information, beyond the ability of evaluators to appreciate them. Consequently, inventors should carefully decide what to include in their proposals, so as to provide a "manageable" yet detailed amount of information.

This finding suggests a tendency for crowds of R\&D professionals to penalize proposals in technological domains that are unfamiliar to them, hence needing more elaborate explanations with since they go beyond what is commonly shared and taken for granted within an R\&D organization. This finding offers the important insight that a crowd is less effective in gauging ideas departing from the current technological competence of a firm; a committee seems more suitable for an indepth analysis of such ideas. Companies should be aware that more complex ideas may be overlooked by crowds, and should therefore instruct committees to focus especially on more articulated proposals. 
Our research has some limitations. First, the innovation contest was designed such that the Screen Team did not evaluate the ideas ranked in the first ten positions in the market. As a result, we cannot fully compare the preference functions of the crowd and the committee. Second, our study is based on a single case and its results cannot be generalized to all firms. However, our case highlights that in high-technology industries characterized by countless complex technological opportunities, preference markets are an efficient mechanism to systematically process these opportunities. We believe that further large-scale studies would contribute greatly to the validation of our findings in this field of research.

Future studies could explore important issues which our work deemphasizes such as the relationship between the diversity of collective decision makers in terms of background and experience and outcomes of the evaluation. Indeed, diversity has been widely acknowledged as a driver of creative outcomes. We took account of diversity only in distinguishing between the broad levels of crowd and committee. It would seem important to understand whether the dimensions of diversity that are conducive to creative outcomes are matched in the evaluating teams, within the context of an innovation contest. Furthermore, more work is needed to disentangle the decision-making dynamics in committees, to better understand how they make use of the information generated by the preference market. This would provide a more thorough assessment of the utility of innovation contests as knowledge management tools. Finally, future studies could address the adoption of preference markets in the later stages of NPD, consistent with the trend towards gamification of an increasing number of business activities (Harman et al. 2014). 


\section{Acknowledgements}

The authors would like to thank Frank Hatzack and Maria Carlsen, who were, when the research was conducted, Senior Innovation Manager and Innovation Specialist at the Novozymes' Innovation Office, and Pernille Helholm, Information Specialist at Novozymes, for their precious and skillful assistance in data collection. Furthermore, they would like to thank Jesper Müller Krogstrup, Partner at NOSCO, for access to the idea market data set.

Research for this paper was funded by Lundbeckfonden, Novo Nordisk Fonden, Novo A/S, Novo Nordisk, and Vækstforum (Region Hovedstaden, Denmark). The authors would like to thank Alan Porter, Nils Brunner, Thomas Mandrup Poulsen, and Toke Reichstein. 


\section{References}

Adamczyk, S., Bullinger, A.C. \& Möslein, K.M., 2012. Innovation Contests: A Review, Classification and Outlook. Creativity and Innovation Management, 21(4), pp.335-360.

Afuah, A. \& Tucci, C.L., 2012. Crowdsourcing As a Solution to Distant Search. Academy of Management Review, 37(3), pp.355-375.

Bayus, B.L., 2013. Crowdsourcing new product ideas over time: An analysis of the Dell IdeaStorm community. Management Science, 59(1), pp.226-244.

Behrens, J., Ernst, H., \& Shepherd, D.A., 2014. The decision to exploit an R\&D project: Divergent thinking across middle and senior managers. Journal of Product Innovation Management, 31(1), pp.144-158

Bentzen, E., Christiansen, J.K. \& Varnes, C.J., 2011. What attracts decision makers' attention? Development portfolio meetings. Management Decision, 49(3), pp.330-349.

Bowen, H.P., 2012. Testing Moderating Hypotheses in Limited Dependent Variable and Other Nonlinear Models: Secondary Versus Total Interactions. Journal of Management, 38(3), pp.860-889.

Bradfield, D. \& Gao, J., 2007. A methodology to facilitate knowledge sharing in the new product development process. International Journal of Production Research, 45(7), pp.1489-1504.

Chan, S.L. \& Ip, W.H., 2010. A Scorecard-Markov model for new product screening decisions. Industrial Management \& Data Sustems, 110(7), pp.971-992. 
Chen, L. et al., 2009. Design and Use of Preference Markets for Evaluation of Early Stage Technologies. Journal of Management Information Sustems, 26(3), pp.45-70.

Ching, C., Holsapple, C.W. \& Whinston, A.B., 1992. Reputation, Learning and Coordination in Distributed Decision-Making Contexts. Organization Science, 3(2), pp.275-297.

Chiu, Y.C., Chen, B., Shyu, J.Z. \& Tzeng, G.H., 2006. An evaluation model of new product launch strategy. Technovation, 26(11), pp.1244-1252.

Citroen, C.L., 2011. The role of information in strategic decision-making. International Journal of Information Management, 31(6), pp.493-501.

Cyert, R.M. \& March, J.G., 1963. A behavioral theory of the firm, Englewood Cliffs, NJ: PrenticeHall.

Demerest, M., 1997. Understanding knowledge management. Journal of Long Range Planning, 30(3), pp. 374-384.

Eling, K., Griffin, A. \& Langerak, F., 2014. Using Intuition in Fuzzy Front-End Decision-Making: A Conceptual Framework. Journal of Product Innovation Management, 31, pp.956-972.

Ferris, G.R. Harris, J.N., Russell, Z.A., Ellen III, B.P., Martinez, A.D., \& Blass, F.R., 2014. The Role of Reputation in the Organizational Sciences: A Multilevel Review, Construct Assessment, and Research Directions. In J.R.B. Halbesleben, A.R. Wheeler, \& M.R. Buckley, eds. Research in Personnel and Human Resources Management, Vol.32. Emerald Group Publishing Limited, pp. 241-303. 
Fleming, L. \& Sorenson, O., 2001. Technology as a complex adaptive system: evidence from patent data. Research Policy, 30(7), pp.1019-1039.

Haas, M.R., Criscuolo, P. \& George, G., 2015. Which Problems to Solve? Attention Allocation and Online Knowledge Sharing In Organizations. Academy of Management Journal, 58(3), pp.658679.

Hanson, R., 2007. Logarithmic Markets Coring Rules for Modular Combinatorial Information Aggregation. The Journal of Prediction Markets, 1(1), pp.3-15.

Harman, K., Koohang, A. \& Paliszkiewicz, J., 2014. Scholarly interest in gamification: a citation network analysis. Industrial Management \& Data Svstems, 114(9), pp.1438-1452.

Ho, C.-F., Hsieh, P.-H. \& Hung, W.-H., 2014. Enablers and processes for effective knowledge management. Industrial Management \& Data Svstems, 114(5), pp.734-754.

Khedhaouria, A. \& Jamal, A., 2015. Sourcing knowledge for innovation: knowledge reuse and creation in project teams. Journal of Knowledge Management, 19(5), pp.932-948

Krishnan, V. \& Ulrich, K.T., 2001. Product development decisions: A review of the literature. Management Science, 47(1), pp.1-21.

LaComb, C.A., Barnett, J.A. \& Pan, Q., 2007. The imagination market. Information Systems Frontiers, 9(2-3), pp.245-256.

Liu, S., 1998. Strategic scanning and interpretation revisiting: foundations for a software agent support system-Part 1: understanding the concept and context of strategic scanning. Industrial Management \& Data Svstems, 98(7), pp.295-312. 
Lounsbury, J.W., Foster, N., Patel, H., Carmody, P., Gibson, L.W., \& Stairs, D.R., 2012. An investigation of the personality traits of scientists versus nonscientists and their relationship with career satisfaction. $R \& D$ Management, 42(1), pp.47-59.

Magnusson, P.R., Netz, J. \& Wästlund, E., 2014. Exploring holistic intuitive idea screening in the light of formal criteria. Technovation, 34(5-6), pp.315-326.

March, J.G. \& Simon, H., 1958. Organizations, New York, NY: Wiley.

Mortara, L., Ford, S.J. \& Jaeger, M., 2013. Idea Competitions under scrutiny: Acquisition, intelligence or public relations mechanism? Technological Forecasting and Social Change, 80(8), pp.1563-1578.

Ocasio, W., 1997. Towards an attention-based view of the firm. Strategic Management Journal, 18(S1), pp.107-206.

Pandey, S. C., \& Dutta, A. 2013. Role of knowledge infrastructure capabilities in knowledge management. Journal of Knowledge Management, 17(3), pp.435-453.

Piezunka, H. \& Dahlander, L., 2014. Distant Search, Narrow Attention: How Crowding Alters Organizations' Filtering of Suggestions in Crowdsourcing. Academy of Management Journal, 58(3), pp.856-880.

Piller, F.T. \& Walcher, D., 2006. Toolkits for idea competitions: a novel method to integrate users in new product development. $R \& D$ Management, 36(3), pp.307-318.

Pitt, M. \& MacVaugh, J., 2008. Knowledge management for new product development. Journal of Knowledge Management, 12(4), pp.101-116. 
Poetz, M.K. \& Schreier, M., 2012. The Value of Crowdsourcing : Can Users Really Compete with Professionals in Generating New Product Ideas? Journal of Product Innovation Management, 29(2), pp.245-256.

Santos, R. \& Spann, M., 2011. Collective entrepreneurship at Qualcomm: combining collective and entrepreneurial practices to turn employee ideas into action. $R \& D$ Management, 41(5), pp.443-456.

Simula, H., \& Ahola, T., 2014. A network perspective on idea and innovation crowdsourcing in industrial firms. Industrial Marketing Management, 43(3), pp.400-408.

Slamka, C., Jank, W. \& Skiera, B., 2012. Second-Generation Prediction Markets for Information Aggregation: A Comparison of Payoff Mechanisms. Journal of Forecasting, 31(6), pp.469489.

Soukhoroukova, A., Spann, M. \& Skiera, B., 2012. Sourcing, Filtering, and Evaluating New Product Ideas: An Empirical Exploration of the Performance of Idea Markets. Journal of Product Innovation Management, 29(1), pp.100-112.

Spears, B. et al., 2009. Examining Trader Behavior in Idea Markets: An Implementation of GE's Imagination Markets. Journal of Prediction Markets, 3(1), pp.17-39.

Subramanian, A.M., Lim, K. \& Soh, P.-H., 2013. When birds of a feather don't flock together: Different scientists and the roles they play in biotech R\&D alliances. Research Policy, 42(3), pp.595-612.

Surowiecki, J., 2004. The Wisdom of Crowds, New York: Doubleday. 
Tripsas, M. \& Gavetti, G., 2000. Capabilities, cognition, and inertia: Evidence from digital imaging. Strategic Management Journal, 21(10/11), pp.1147-1161.

Vaccaro, A., Parente, R., \& Veloso, F.M., 2010. Knowledge management tools, inter-organizational relationships, innovation and firm performance. Technological Forecasting and Social Change, 77(7), 1076-1089.

Van Dijk, C. \& Van den Ende, J., 2002. Suggestion systems: transferring employee creativity into practicable ideas. R\&D Management, 32(5), pp.387-395.

Xu, Y., Bernard, A., Perry, N., Xu, J., \& Sugimoto, S. 2014. Knowledge evaluation in product lifecycle design and support. Knowledge-Based Systems, 70, pp.256-267.

Yang, J. \& Rui, M., 2009. Turning knowledge into new product creativity: an empirical study. Industrial Management \& Data Svstems, 109(9), pp.1197-1210.

Zhen, L., Wang, L., \& Li, J.G., 2013. A design of knowledge management tool for supporting product development. Information Processing \& Management, 49(4), pp.884-894. 


\section{Biographical end note}

Giancarlo Lauto is assistant professor of Organization Studies at the Department of Economics and Statistics, University of Udine. His research interests lie in the following areas: management of innovation and growth patterns in SMEs, organization of scientific research, technology transfer and academic entrepreneurship. He has been a post-doc at Copenhagen Business School and a visiting scholar at Kyoto University and Tokyo Institute of Technology.

Finn Valentin is Professor at the Department of Innovation and Organizational Economics at Copenhagen Business School. He is the Director of the Research Centre on Biotech Business and the director of the Master's Program in BioBusiness and Innovation offered jointly by three universities in the Copenhagen region. His publications cover issues in $R \& D$ strategy and the commercialization of science. 
Table 1. Demographic profile of participants in Grow Bets 2011.

\begin{tabular}{ll}
\hline Gender & N. $(\%)$ \\
\hline Male & $82(75 \%)$ \\
Female & $27(25 \%)$ \\
\hline Age class & $22(20 \%)$ \\
\hline$<36$ & $16(15 \%)$ \\
$36-40$ & $35(32 \%)$ \\
$41-45$ & $17(16 \%)$ \\
$46-50$ & $18(17 \%)$ \\
$>50$ & $1(1 \%)$ \\
N/A & \\
\hline Location & $55(50 \%)$ \\
Denmark & $19(17 \%)$ \\
Rest of the World & $35(32 \%)$ \\
USA & \\
\hline Seniority & $32(29 \%)$ \\
\hline 0-4 & $16(15 \%)$ \\
5-9 & $29(27 \%)$ \\
$15-19$ & $13(12 \%)$ \\
20+ & $18(16 \%)$ \\
N/A & $1(1 \%)$ \\
\hline
\end{tabular}


Table 2. Variables and measures.

\begin{tabular}{|c|c|}
\hline Variable & Measure \\
\hline \multicolumn{2}{|l|}{ Dependent variables } \\
\hline Final Market Value (FMV) & Value of ideas at market close, divided by 1000. \\
\hline Screen Team Choice (STC) & $\begin{array}{l}\text { Value } 1 \text { if the Screen Team admitted the idea to the next step of the contest, } \\
\text { and value } 0 \text { otherwise. }\end{array}$ \\
\hline \multicolumn{2}{|l|}{ Explanatory variables } \\
\hline Patent & $\begin{array}{l}\text { Value } 1 \text { if at least one of the inventors had registered a patent before the } \\
\text { competition, and value } 0 \text { otherwise. }\end{array}$ \\
\hline Article & $\begin{array}{l}\text { Value } 1 \text { if at least one of the inventors had published a scientific article before } \\
\text { the competition, and value } 0 \text { otherwise. }\end{array}$ \\
\hline Idea Web & $\begin{array}{l}\text { Value } 1 \text { if at least one of the inventors had submitted a proposal to Idea Web } \\
\text { before the competition, and value } 0 \text { otherwise. Idea Web is an internal virtual } \\
\text { idea repository on which employees can post new product idea proposals for } \\
\text { screening by R\&D managers }{ }^{1} \text {. }\end{array}$ \\
\hline Seniority & The number of years the leading inventor has been working at Novozymes. \\
\hline Words & The number of words of the textual description of the idea. \\
\hline Link & Value 1 if the idea description includes a link, and value 0 otherwise. \\
\hline Attachment & Value 1 if the idea description includes an attachment, and value 0 otherwise. \\
\hline \multicolumn{2}{|l|}{ Control variables } \\
\hline Inventors & $\begin{array}{l}\text { The number of inventors. It captures the potential for knowledge } \\
\text { recombination in a team. }\end{array}$ \\
\hline Days Traded & $\begin{array}{l}\text { The number of days an idea has been up for trading. It affects FMV because } \\
\text { the ideas that have been submitted later had fewer opportunities to be traded. }\end{array}$ \\
\hline Submissions & $\begin{array}{l}\text { Number of ideas submitted by inventors. More prolific inventors may be } \\
\text { more creative, but may also be less focused on strengthening their many } \\
\text { proposals. }\end{array}$ \\
\hline Location & $\begin{array}{l}\text { Distinguishes three locations: Denmark, USA, and the Rest of the World, that } \\
\text { comprises Brazil, China, India and Japan. Screen Team or traders may be } \\
\text { biased towards ideas submitted by inventors working in specific research } \\
\text { sites. }\end{array}$ \\
\hline
\end{tabular}

1 We gathered data on patenting, publishing and contribution to Idea Web from the records of the Human Resources and Library departments of Novozymes, and validated them with searches for patents in the Derwent World Patent Index database, and for articles in the ISI-Web of Science database. 
Table 3 Descriptive statistics on the relationship of categorical variables with FMV and STC.

\begin{tabular}{|c|c|c|c|}
\hline & N. (\%) & $\begin{array}{c}\text { FMV } \\
\text { Mean (Median) }\end{array}$ & $\begin{array}{c}\text { STC } \\
\text { N. (\%) }\end{array}$ \\
\hline & & & \\
\hline IdeaWeb & & & $11(78.6 \%)$ \\
\hline Yes & $112(55.7 \%)$ & $2167(1436)$ & $3(21.4 \%)$ \\
\hline No & $89(44.3 \%)$ & $3100(1858)$ & $12(85.7 \%)$ \\
\hline Patent & & $2032(1210)$ & $2(14.3 \%)$ \\
\hline Yes & $156(77.6 \%)$ & & $8(57.1 \%)$ \\
\hline No & $45(22.4 \%)$ & $2972(1687)$ & $6(42.8 \%)$ \\
\hline Article & $139(69.2 \%)$ & $2611(1440)$ & $1(7.1 \%)$ \\
\hline Yes & $62(30.8 \%)$ & & $13(92.9 \%)$ \\
\hline No & $19(9.5 \%)$ & $2588(2223)$ & $4(28.6 \%)$ \\
\hline Attachments & $182(90.5 \%)$ & $2889(1642)$ & $10(71.4 \%)$ \\
\hline Yes & & & \\
\hline No & $30(14.9 \%)$ & $1808(743)$ & $7(50.0 \%)$ \\
\hline Link & $171(85.1 \%)$ & $3046(1832)$ & $5(35.7 \%)$ \\
\hline Yes & $75(37.3 \%)$ & $3769(2619)$ & $2(14.3 \%)$ \\
\hline No & $54(26.9 \%)$ & $2940(933)$ & $1855(490)$ \\
\hline Location & $72(35.8 \%)$ & & \\
\hline Denmark & & & \\
\hline USA & & & \\
\hline Rest of the World & & & \\
\hline
\end{tabular}


Table 4 Descriptive statistics on the relationship of continuous variables with FMV and STC.

\begin{tabular}{|l|c|c|c|}
\hline & Mean (Median) & Mean (Median) & Correlation with FMV \\
\hline & for STC $(\mathrm{n}=14)$ & for not STC $(\mathrm{n}=187)$ & $(\mathrm{n}=201)$ \\
\hline Seniority & $11.857(10)$ & $9.995(10)$ & 0.050 \\
\hline Words & $208(201)$ & $188(153)$ & $0.128^{*}$ \\
\hline Days traded & $6.786(6)$ & $6.390(5)$ & -0.068 \\
\hline Inventors & $1.143(1)$ & $1.155(1)$ & -0.102 \\
\hline Submissions & $4.500(3)$ & $6.642(5)$ & $-0.145^{* *}$ \\
\hline
\end{tabular}


Table 5 Results of regressions

\begin{tabular}{|c|c|c|c|c|c|c|c|c|}
\hline & $\begin{array}{c}\text { Model 1 } \\
\text { Probit } \\
\text { DV: STC }\end{array}$ & & \begin{tabular}{|c|} 
Model 2 \\
Tobit \\
DV: FMV
\end{tabular} & & \begin{tabular}{|c|} 
Model 3 \\
Tobit \\
DV: FMV \\
\end{tabular} & & $\begin{array}{c}\text { Model } 4 \\
\text { Tobit } \\
\text { DV: FMV } \\
\end{array}$ & \\
\hline & Coef. & M.E. & Coef. & M.E. & Coef. & M.E. & Coef. & M.E. \\
\hline Idea Web & $\begin{array}{l}0.821^{* * *} \\
(0.295)\end{array}$ & $\begin{array}{l}0.045^{* *} \\
(0.025)\end{array}$ & $\begin{array}{l}1507^{*} \\
(844)\end{array}$ & $\begin{array}{c}877.9^{*} \\
(474.2)\end{array}$ & $\begin{array}{c}1562^{*} \\
(836.9)\end{array}$ & $\begin{array}{l}907.6^{*} \\
(469.6)\end{array}$ & $\begin{array}{l}1571^{*} \\
(850.7)\end{array}$ & $\begin{array}{l}920.4^{*} \\
(480.5)\end{array}$ \\
\hline Patent & $\begin{array}{l}0.435^{*} \\
(0.228)\end{array}$ & $\begin{array}{c}0.032^{*} \\
(0.019)\end{array}$ & $1015(746)$ & $\begin{array}{c}609.6 \\
(437.1) \\
\end{array}$ & $\begin{array}{c}907.7 \\
(729.2)\end{array}$ & $\begin{array}{c}549.2 \\
(431.1) \\
\end{array}$ & $\begin{array}{l}1036.5 \\
(779.1)\end{array}$ & $\begin{array}{c}627.8 \\
(456.9) \\
\end{array}$ \\
\hline Article & $\begin{array}{c}-0.968^{* * *} \\
(0.359)\end{array}$ & $\begin{array}{l}-0.203^{* *} \\
(0.101)\end{array}$ & $\begin{array}{l}-65.01 \\
(1055)\end{array}$ & $\begin{array}{l}-41.57 \\
(676.5)\end{array}$ & $\begin{array}{l}-37.48 \\
(1044)\end{array}$ & $\begin{array}{l}-23.97 \\
(668.8)\end{array}$ & $\begin{array}{l}232.1 \\
(1074)\end{array}$ & $\begin{array}{c}147.5 \\
(676.3)\end{array}$ \\
\hline Seniority & $\begin{array}{l}0.043^{* *} \\
(0.019)\end{array}$ & $\begin{array}{l}0.005^{* * *} \\
(0.002)\end{array}$ & $\begin{array}{l}-4.771 \\
(48.54) \\
\end{array}$ & $\begin{array}{r}-3.040 \\
(31.01) \\
\end{array}$ & $\begin{array}{l}-8.839 \\
(48.46) \\
\end{array}$ & $\begin{array}{l}-5.641 \\
(31.07) \\
\end{array}$ & $\begin{array}{l}-7.053 \\
(48.30) \\
\end{array}$ & $\begin{array}{c}-4.541 \\
(31.21) \\
\end{array}$ \\
\hline Link & $\begin{array}{c}0.473 \\
(0.435)\end{array}$ & $\begin{array}{c}0.073 \\
(0.092)\end{array}$ & $\begin{array}{l}-1823^{* *} \\
(787.4)\end{array}$ & $\begin{array}{c}-1042^{* * * * 4} \\
(391.6)\end{array}$ & $\begin{array}{c}228.1 \\
(1228)\end{array}$ & $\begin{array}{l}-811.1^{* * *} \\
(384.7)\end{array}$ & $\begin{array}{l}-1855^{* *} \\
(771.8)\end{array}$ & $\begin{array}{l}1067^{* \ldots+2} \\
(382.9)\end{array}$ \\
\hline Attachments & $\begin{array}{l}-0.329 \\
(0.606) \\
\end{array}$ & $\begin{array}{l}-0.027 \\
(0.037) \\
\end{array}$ & $\begin{array}{l}-235.7 \\
(922.6) \\
\end{array}$ & $\begin{array}{l}-147.5 \\
(574.5)\end{array}$ & $\begin{array}{l}-319.4 \\
(901.0)\end{array}$ & $\begin{array}{l}-200.1 \\
(557.2)\end{array}$ & $\begin{array}{l}67.69^{* * * *} \\
(1.255)\end{array}$ & $\begin{array}{l}43.75^{* *} \\
(505.6)\end{array}$ \\
\hline Words & $\begin{array}{c}0.473 \\
(0.435) \\
\end{array}$ & $\begin{array}{c}-9.31 * 10^{\wedge-6} \\
\left(9^{*} 10^{\wedge-6}\right)\end{array}$ & $\begin{array}{l}6.551^{\text {*** }} \\
(2.409)\end{array}$ & $\begin{array}{l}4.174^{* * *} \\
(1.530)\end{array}$ & $\begin{array}{l}8.150^{* * *} \\
(2.813)\end{array}$ & $\begin{array}{l}5.201^{* * *} \\
(1.811)\end{array}$ & $\begin{array}{l}8.394^{* * * *} \\
(2.566)\end{array}$ & $\begin{array}{l}5.404^{* * *} \\
(1.659)\end{array}$ \\
\hline Link*Words & & & & & $\begin{array}{l}-8.507^{*} \\
(4.381)\end{array}$ & $\begin{array}{l}-5.429^{*} \\
(2.855)\end{array}$ & & \\
\hline $\begin{array}{l}\text { Attachments* } \\
\text { Words }\end{array}$ & & & & & & & $\begin{array}{c}-16.35^{* * *} \\
(3.995)\end{array}$ & $\begin{array}{c}-10.53^{* * *} \\
(2.583)\end{array}$ \\
\hline Inventors & $\begin{array}{c}-0.011 \\
(0.238) \\
\end{array}$ & $\begin{array}{c}-0.001 \\
(0.025) \\
\end{array}$ & $\begin{array}{l}-500.4 \\
(359.7) \\
\end{array}$ & $\begin{array}{c}-318.8 \\
(236.6)\end{array}$ & $\begin{array}{l}-398.9 \\
(344.2) \\
\end{array}$ & $\begin{array}{c}-254.6 \\
(225.2)\end{array}$ & $\begin{array}{l}-584.3 \\
(365.5)\end{array}$ & $\begin{array}{l}-376.20 \\
(244.8)\end{array}$ \\
\hline Submissions & $\begin{array}{l}-0.063^{*} \\
(0.034)\end{array}$ & $\begin{array}{l}-0.007 \\
(0.005)\end{array}$ & $\begin{array}{l}-148.4 \\
(94.63)\end{array}$ & $\begin{array}{l}-94.53 \\
(60.69)\end{array}$ & $\begin{array}{l}-143.2 \\
(93.27)\end{array}$ & $\begin{array}{l}-91.41 \\
(60.10)\end{array}$ & $\begin{array}{l}-158.0 \\
(95.20)\end{array}$ & $\begin{array}{l}-101.7 \\
(61.92)\end{array}$ \\
\hline \multicolumn{9}{|l|}{ Region } \\
\hline USA & $\begin{array}{c}0.307 \\
(0.309)\end{array}$ & $\begin{array}{c}0.042 \\
(0.048)\end{array}$ & $\begin{array}{l}-594.3 \\
(865.7)\end{array}$ & $\begin{array}{l}-365.9 \\
(523.1)\end{array}$ & $\begin{array}{l}-559.9 \\
(853.5)\end{array}$ & $\begin{array}{l}-345.9^{*} \\
(517.3)\end{array}$ & $\begin{array}{l}-414.5 \\
(889.7)\end{array}$ & $\begin{array}{l}-260.6 \\
(551.5)\end{array}$ \\
\hline $\begin{array}{l}\text { Rest of the } \\
\text { World }\end{array}$ & $\begin{array}{l}-0.310 \\
(0.371)\end{array}$ & $\begin{array}{l}-0.026 \\
(0.028)\end{array}$ & $\begin{array}{l}-1755 \\
(1233)\end{array}$ & $\begin{array}{l}-1007 \\
(635.6)\end{array}$ & $\begin{array}{l}-1815.8 \\
(1202.8)\end{array}$ & $\begin{array}{r}-1038.8^{*} \\
(613.0)\end{array}$ & $\begin{array}{l}-1651 \\
(1226)\end{array}$ & $\begin{array}{l}-962.7 \\
(645.0)\end{array}$ \\
\hline Days traded & $\begin{array}{l}0.049^{*} \\
(0.028)\end{array}$ & $\begin{array}{c}0.005 \\
(0.004)\end{array}$ & $\begin{array}{l}98-.16 \\
(73.62)\end{array}$ & $\begin{array}{c}62.55 \\
(47.53)\end{array}$ & $\begin{array}{c}88.53 \\
(73.70)\end{array}$ & $\begin{array}{c}56.50 \\
(47.68)\end{array}$ & $\begin{array}{c}96.21 \\
(72.59)\end{array}$ & $\begin{array}{c}61.65 \\
(47.513)\end{array}$ \\
\hline Constant & $\begin{array}{c}-2.270^{* * * *} \\
(0.463)\end{array}$ & & $\begin{array}{l}1424^{* *} \\
(1072)\end{array}$ & & $\begin{array}{l}1145.7 \\
(1090)\end{array}$ & & $\begin{array}{c}2530 \\
(1097)\end{array}$ & \\
\hline $\begin{array}{l}\text { Log pseudo- } \\
\text { likelihood }\end{array}$ & -1539 & & -1539 & & -1539 & & -1537 & \\
\hline Sigma & & & $3942(267)$ & & $3918(269)$ & & $\begin{array}{c}3.887 \\
(0.269)\end{array}$ & \\
\hline
\end{tabular}

Notes: Observations $=201$. Robust standard errors in parentheses. 
Table 6 Marginal effects of presence of links and attachments on FMV at relevant percentiles of Words.

\begin{tabular}{|l|c|c|c|c|c|}
\hline $\begin{array}{c}\text { Percentile of } \\
\text { Words }\end{array}$ & $\begin{array}{c}\text { N. of } \\
\text { ideas }\end{array}$ & $\begin{array}{c}\text { Marginal effect of } \\
\text { links }\end{array}$ & $\begin{array}{c}\text { N. of proposals } \\
\text { with links }\end{array}$ & $\begin{array}{c}\text { Marginal effect of } \\
\text { attachment }\end{array}$ & $\begin{array}{c}\text { N. of proposals } \\
\text { with attachments }\end{array}$ \\
\hline Minimum $(17)$ & 1 & $53.52(753.1)$ & $0(0 \%)$ & $2129^{* *}(968.9)$ & $0(0 \%)$ \\
\hline $10^{\text {th }}(64)$ & 19 & $-198.2(619.9)$ & $1(5.3 \%)$ & $1513^{* *}(815.4)$ & $1(5.3 \%)$ \\
\hline $25^{\text {th }}(103)$ & 31 & $-398.3(525.5)$ & $2(6.5 \%)$ & $1026(699.2)$ & $2(6.5 \%)$ \\
\hline $50^{\text {th }}(155)$ & 50 & $-652.5(427.8)$ & $5(10 \%)$ & $415.6(600.0)$ & $4(8 \%)$ \\
\hline $75^{\text {th }}(241)$ & 50 & $-1041^{* * * *}(354.0)$ & $9(18 \%)$ & $-481.2(441.4)$ & $7(14 \%)$ \\
\hline $90^{\text {th }}(348)$ & 30 & $-1474^{\text {**** }}(396.9)$ & $6(20 \%)$ & $-1396^{* * * *}(414.3)$ & $3(10 \%)$ \\
\hline Maximum $(815)$ & 20 & $-4427^{* * *}(1559)$ & $7(35 \%)$ & $-5705^{* * *}(1206)$ & $2(10 \%)$ \\
\hline
\end{tabular}




\section{Figure 1. Major advantages of innovation contests in the NPD process.}
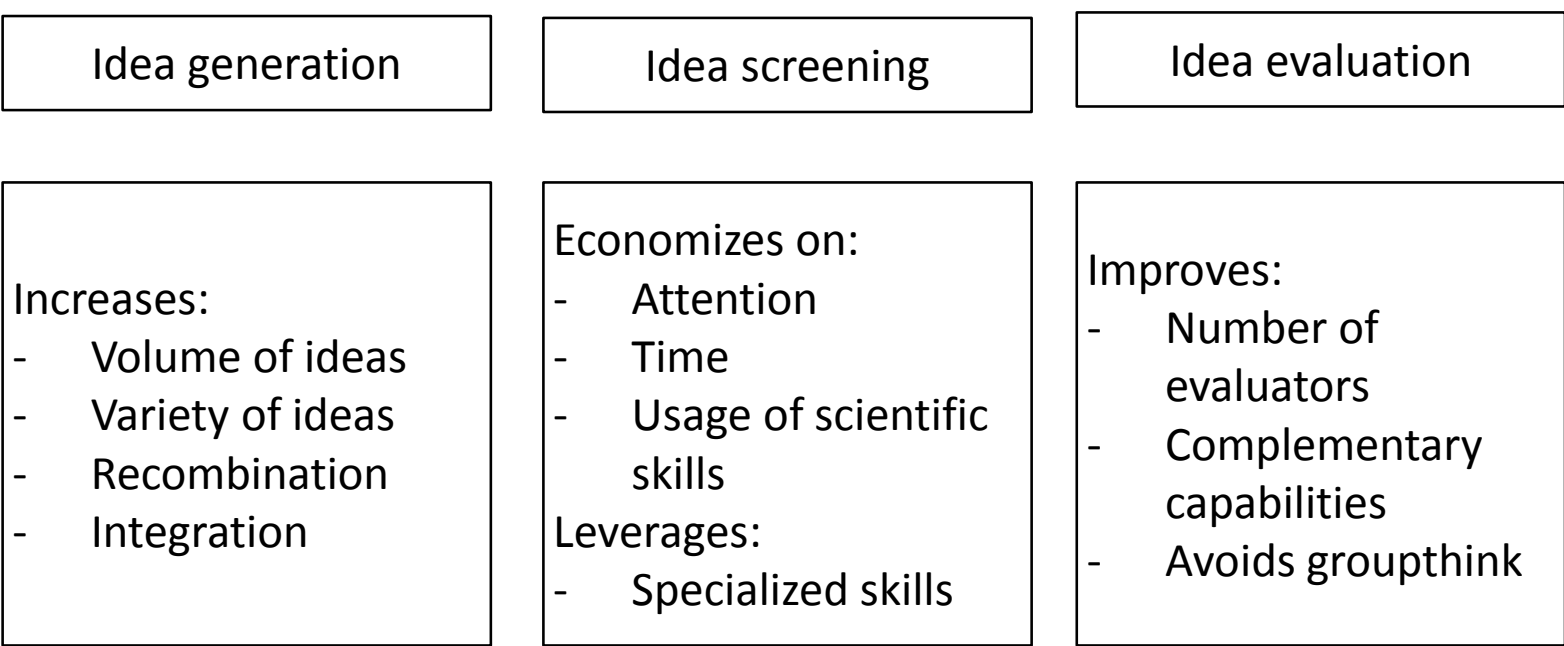

Mat

Economizes on:

- Attention

- Time

- Usage of scientific skills

Leverages:

- $\quad$ Specialized skills

Improves:

- Number of

evaluators

- Complementary

capabilities

- Avoids groupthink

\section{Innovation contests}




\section{Figure 2. Graphical representation of the conceptual model.}

\section{Characteristics of inventors \\ Creativity \\ Inventive experience \\ Patenting experience \\ Scientific experience \\ Seniority in the firm}

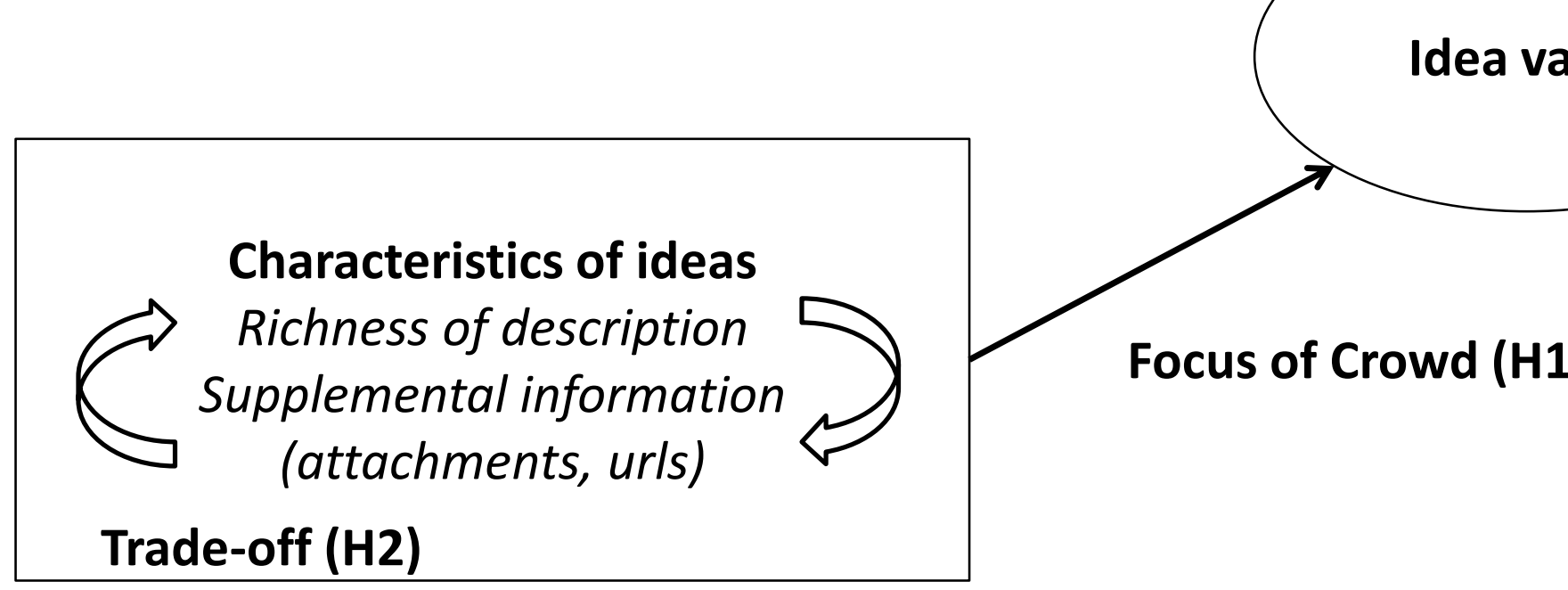

